\title{
Labor Unrest in the Ready-Made Garment Industry of Bangladesh : Causes and Consequences
}

\author{
Sabbrina Choudhury, MBA \\ Md. Habibur Rahman, MSc.
}

Lecturer, Department of Business Administration,

BGMEA University of Fashion \& Technology, Dhaka, Bangladesh

Doi: 10.19044/esj.2017.v13n34p87 URL:http://dx.doi.org/10.19044/esj.2017.v13n34p87

\begin{abstract}
Labor unrest is a very recurrent circumstance in the garment's industry of Bangladesh. Violent protest and agitation by workers has become a common feature in garment's industry. So take into account, we examine the main causes and consequences behind the labor unrest of Ready-Made Garment (RMG) industry in Bangladesh. Data for the study was collected from different garment factories of Dhaka, Ashulia, Tongi, Mirpur, Mohakhali, Gazipur, Narayangang and Savar. Face to face interview and questionnaire method have been used for collecting data of this study. The findings show that the low wage and long working hour are the main causes of labor unrest in the RMG industry of Bangladesh that, in turn, create job dissatisfaction. If the policy makers of RMG industry consider these causes and consequences and take required steps to overcome these problems, the labor unrest in garment industry will be eliminated. Additionally, we identify future research areas that provide scholars opportunities to push theoretical boundaries and offer further insights into the labor unrest.
\end{abstract}

Keywords: Labor unrest, ready-made garment, causes of labor unrest, consequences of labor unrest

\section{Introduction}

The RMG industry has accomplished a remarkable growth since the 1980s. This industry contributes significantly to the Gross Domestic Product (GDP) of Bangladesh. It has become the lifeline of Bangladeshi economy creating opportunities for jobs, income and exports (Kamal, Billah \& Hossain, 2012). RMG industries are labor intensive. It has been giants through its low cost labor. The labor intensiveness and the cheapest labor cost are considered as the major contributing factors for the embellishment (Islam \& Zahid, 2012). RMG industries are playing a very important role in 
the economic development of Bangladesh. Contribution of the RMG industry in national economy is great. It is the highest foreign exchange earner.

\begin{tabular}{|c|c|c|c|}
\hline Year & $\begin{array}{c}\text { Export of RMG (In } \\
\text { Million USD) }\end{array}$ & $\begin{array}{c}\text { Total Export of } \\
\text { Bangladesh (In } \\
\text { Million USD) }\end{array}$ & $\begin{array}{c}\text { Percentage of RMG's } \\
\text { to Total Export }\end{array}$ \\
\hline $2000-01$ & 4859.83 & 6467.30 & $75.14 \%$ \\
\hline $2001-02$ & 4583.75 & 5986.09 & $76.57 \%$ \\
\hline $2002-03$ & 4912.09 & 6548.44 & $75.01 \%$ \\
\hline $2003-04$ & 5686.09 & 7602.99 & $74.79 \%$ \\
\hline $2004-05$ & 6417.67 & 8654.52 & $74.15 \%$ \\
\hline $2005-06$ & 7900.80 & 10526.16 & $75.06 \%$ \\
\hline $2006-07$ & 9211.23 & 12177.86 & $75.64 \%$ \\
\hline $2007-08$ & 10699.80 & 14110.80 & $75.83 \%$ \\
\hline $2008-09$ & 12347.77 & 15565.19 & $79.33 \%$ \\
\hline $2009-10$ & 12496.72 & 16204.65 & $77.12 \%$ \\
\hline $2010-11$ & 17914.46 & 22924.38 & $78.15 \%$ \\
\hline $2011-12$ & 19089.69 & 24287.66 & $78.60 \%$ \\
\hline $2012-13$ & 21515.73 & 27027.36 & $79.61 \%$ \\
\hline $2013-14$ & 24491.88 & 30186.62 & $81.13 \%$ \\
\hline $2014-15$ & 25491.40 & 31198.45 & $81.71 \%$ \\
\hline $2015-16$ & 28090 & 34240 & $82.04 \%$ \\
\hline
\end{tabular}

Table-1: Comparison between Export of RMG and Total Export of Bangladesh (Source: Hasan, Islam \& Arifuzzaman, 2015)

RMG industry is infested with a number of problems; labor unrest is one of the major problems. This industry is now in crisis due to repetitive workers agitation. Labor unrest is a common phenomenon in the RMG industry of Bangladesh. There are various examples of workers being enmeshed in conflicts; strikes are being called by them in order to meet their demands. Owners face losses, the economy of the country usually slows down and it fades the reputation of the country as well. Foreign buyers think twice and add new conditions due to those kinds of strikes. This causes the industry to lose the core competency edge. The reasons behind those unrests are more than just one. There is a long history of grievance of the workers. First and foremost is the long-standing grievance of the workers. The growth of the industry is mainly based on the hard works done by the workers. The low cost of labor is also the most important core competency of this industry. But in the reality they are the ones who are deprived of the minimum level of amenities. The growth of RMG industry of Bangladesh much depends on hard work of the labor force. Let alone amenities they often don't get their bonuses and salaries and also overtimes. They are the main power behind the growth but they don't get to decide their fate. Keeping the importance of the ready-made garment industry in the economy of Bangladesh in mind, this study mainly identified the reasons for the continuous labor unrest in this industry of Bangladesh (Ahmed, Raihan, \& Islam, 2013). 
On the basis of these arguments, the aim of this research is therefore to explore the real fact and causes and consequences behind the labor unrest and find the more scopes for the development of RMG industry by reducing the existing limitation. This paper is based on data collected from both management (owners and managers) and workers by visiting garments premises as well as houses of workers to gather information. The primary and secondary data has been used throughout this research paper to meet this objective. For this reason we systematically examine previous research on these topics of RMG industry.

The research paper is constructed as follows: After the brief introduction in Section 1, Section 2 includes review of the literature, while Section 3 shows the research methodology of of this study. We present the overall research findings in section 4, followed by analysis and recommendation in section 5 and 6 respectively. Finally, Section 7 concludes the paper by describing the implications and limitations of the study, and by suggesting future research directions.

\section{Review of the Literature}

The ready-made garment (RMG) industry is under the risk of endless unrest in Bangladesh. Most of the workers are unhappy with their current wages and working environments of the factories. On December, 2016, the labor unrest was occurred due to wage hike. The leaders demanded withdrawal of all cases filed against apparel workers. The leaders also opinioned the minimum wage of a worker should be enhanced to Tk. 16,000 from the current wage of Tk. 5,300 (Bangladesh, 2017). On December 23, 2016, Bangladesh garment factories sacked 1,500 workers because of protests compelled a week long closing at dozens of sites supplying top European and American brands (Safi, 2016).

The issue of labor unrest related to both worker's wages and nonwage issues for example, high overtime work, lack of leisure and holidays, overall working environment, etc. The clash between garment's workers and law enforces generate a great crisis in this industry (Islam \& Ahmad, 2010). On January 11, 2010, the garment workers made violence for having the advantages such as encashment of casual leaves and lunch bills. The productions of 30 garment factories were stopped and 40 workers were severely injured. The garment workers also created another movement on April 28, 2010 for raising their monthly wage rate from US\$ 25 to US\$ 70 . For this movement, 30 people were injured and more than $22 \mathrm{RMG}$ factories were affected. The rate of wage (0.25 US\$ hour) is the lowest in Bangladesh comparing with other countries like China (0.35), Vietnam (0.40), Pakistan (0.40) and India (0.60) (Siddiqi, 2005). The overtime payment is also insufficient in the garment industry of Bangladesh (Sarker, 1997). 
The most important reasons of labor unrest in the Bangladesh's garment industry are unpaid wage and the delayed payment. The wages of the garment workers are not sufficient to survive. A few garment owners don't give salaries and overtime payment timely (Uddin \& Jahed, 2007). But the owners of the garment industry claim that more than $90 \%$ garments factories pay worker's salaries within $1^{\text {st }}$ and $2^{\text {nd }}$ week of the month (Rahman, Bhattacharya, \& Moazzem, 2008). Absar (2001) states that substandard living condition and low wages are the main causes of labor unrest in the RMG industry of Bangladesh. Recently the Ashulia's labor unrest has spread to many other apparel hubs as the workers took to the streets to show solidarity with their colleagues and demand wage hike. Abrar Ahmed Apu (2007) stated that higher wage discrimination in the organizational hierarchy, low wages, lack of compliance (no festival bonus, no weekend, obligatory over time, devoid of payment), lack of responsible organizations who will listen labors' needs and demands; sudden death of any garment worker in the factory, pregnancy of women, ill minded male workers create troubles to get their illogical demands, local influential, Jhoot (Jhoot refers to the trade of garments wastes by the local language of Bangladesh), mostly generates unwanted labor unrest in the RMG industry.

Generally the women workers work till 3 o'clock in the morning for completing their shipment deadlines (Jamaly \& Wickramnanyam, 1996). The daily working hour in the most of the RMG factories is 8.28 hours (Rahman, Bhattacharya, \& Moazzem, 2008). Normally the women come to work in the RMG factories because of their poor economic condition with the lack of control over their income (Paul- Majumder, 1998). On the other hand, women face discriminations at work regarding wage and gender differences. In most cases, they work in poor condition and feel unsecured (Hossain, Jahan, \& Sobhan, 1990). Most of the women workers in the garment's industry live under the poverty line due to their low wage. Even they can't manage their basic living cost so that they try to enhance their income performing overtime work (Absar, 2001; Clark \& Kanter, 2010). The minimum wage of USD 43 per month has not yet implemented until 2010. Paul-Majumder (2007) identified that the demand for weekly holiday is a main cause for labor unrest during 2006. It is noticed that the garment's workers are involved in working for the whole week. Blaming mistrust, rude behaviors of the managers are the causes of labor unrest in the RMG industry of Bangladesh.

The declarations of closure or lay-off, reduction of leave or holiday were the causes of labor unrest in the RMG industry. Daily Star (May, 2012) stated that the garment workers involve in severe clashes because of rumors or simple instigation and bad relation with the management. Regardless the massive labor unrest for wage hike in 2010, the other incidents of labor 
unrest occurred either the rumor of death of the fellow worker or on instigation. Refaue Ullah Mirdha (2012) explored that the fear of job loss, rumor, jhoot business, arrears, shutdown of factories, police cases, pay hike and discrimination in grades, poor relation with workers and managers, local influential, international conspirator, cutting orders by foreign buyers, higher house rent, lack of proper training program etc. are the causes of labor unrest in the RMG industry of Bangladesh.

A major labor unrest took place on May 25, 2010 because of low house rent allowance. A police station was burned, thirty people were wounded and many roads were obstructed for some hours. The garment's workers involved in a movement at Dhaka on June 30, 2010 for not closing the factories and more than 40 workers were wounded. They engaged in a street protest, blocked of a manager's office to inform their dissatisfaction about their wages and other job related matters (Islam \& Ahmad, 2010). Mohammad Sirajul Islam and Sonia Ahmad (2010) stated that increasing of casual leave and lunch bill, enhancing monthly wages from Tk. 1662 to Tk. 5000 and better supply of gas and water are the reasons of labor unrest in the RMG industry of Bangladesh. There are also several prominent causes that lessen the productivity in the RMG industry. The issues include unresolved labor clashes and poor teamwork performance result in firm's ineffectiveness, fast technological change, lower motivation and high cost (Abdullah, 2005).

The legal and institutional failure is also a cause of labor unrest in the garment industry of Bangladesh. Most of the garment factories in Bangladesh don't follow the labor laws and International Labor Organization (ILO) conventions properly. In the garment industry, the rights of the labors are not maintained properly. The child labors are permitted to work in the garment factories. The Labor Act 2006 apparently clarifies that the wage of the worker should be paid within seven working days [Section 123 (1)]. Most of the garment factories don't give any appointment letters, employee handbooks and identity cards. The security condition and health safety are also inadequate in the garment industries. The workers don't have any proper idea regarding their rights and labor laws (Islam \& Ahmed, 2010).

The national political environment has notable impact on the labor unrest in the RMG industries that is explored from the study of Uddin and Jahed (2007). New Age Metro (2008) stated that the RMG industry of Bangladesh has faced approximately 72 incidents of labor unrest because of the deferred payment of salaries. According to the Bangladesh Institute of Labor Studies, 41 of the incidents occurred due to the demand for payment of their dues. In 13 cases, the workers went to streets for the movement because of the killing or torture of their fellow workers. 


\section{Research Methodology}

This study incorporated a qualitative research approach to tackle the research questions. This study is based on both primary and secondary sources of data. Data collection has been done through face-to-face in-depth interview and informal conversations from randomly selected RMG factories at areas of Dhaka. In this study, 40 workers, 5 managers and 5 owners were interviewed from the different garments factories. The secondary data have been collected from the journals, periodicals, annual reports of Bangladesh Garment Manufacturers and Exporters Association (BGMEA), relevant publications, newspaper articles and reports, website etc.

The most crucial part of this research is interview with a wide range of garment workers, factory managers and owners from garment factories of different areas. The interviewees were asked semi-structured questions about the origin of labor unrest and eventually generated the stories they experienced. In the interviews they shared their problems and experiences related to their work. In this research study, all the interviews have been recorded and all the feedback by the participants have been noted down. Transcripts were made following the tape and notes. So this research has selected case studies from many participants who directly or indirectly connected with garments industry. The stories were developed from the transcripts later on.

\section{Demographic Profile}

Of 50 respondents, 14 are males and 36 are females. About $28 \%$ respondents were male, and $72 \%$ were female. Majority of the respondents had at least higher secondary education (30\%) and aged under $35(80 \%)$. A snapshot of socio-economic background of the respondents is presented in table-2.

\begin{tabular}{|c|c|c|c|}
\hline Category & Sub-Category & Frequency & Valid Percentage \\
\hline \multirow{3}{*}{ Gender } & Male & 14 & 28 \\
\cline { 2 - 4 } & Female & 36 & 72 \\
\cline { 2 - 4 } & Total & 50 & 100 \\
\hline \multirow{4}{*}{ Occupation } & Worker & 40 & 80 \\
\cline { 2 - 4 } & Owner & 5 & 10 \\
\cline { 2 - 4 } & Manager & 50 & 10 \\
\cline { 2 - 4 } & Total & 3 & 100 \\
\hline \multirow{5}{*}{ Education } & Illiterate & 8 & 6 \\
\cline { 2 - 4 } & Primary & 12 & 16 \\
\cline { 2 - 4 } & Secondary & 15 & 30 \\
\cline { 2 - 4 } & Higher Secondary Certificate & 12 & 24 \\
\cline { 2 - 4 } & (HSC) & 50 & 100 \\
\cline { 2 - 4 } & Above HSC & 23 & 46 \\
\hline & Total & & \\
\hline
\end{tabular}




\begin{tabular}{|c|c|c|c|}
\hline \multirow{3}{*}{ Age } & $25-34$ & 17 & 34 \\
\cline { 2 - 4 } & $35-44$ & 4 & 8 \\
\cline { 2 - 4 } & $45-$ Above & 6 & 12 \\
\cline { 2 - 4 } & Total & 50 & 100 \\
\hline
\end{tabular}

Table-2: Socio-economic background of the respondents

\section{Findings}

In this section we have tried to focus on the causes of labor unrest in the garment's industry of Bangladesh from the garment's workers. Though the total number of respondents is 50 , we only present 10 stories, which are representative and have significant reason, in this paper for the reason of page limitation. The results of the study show that the workers of the garment's industry in Bangladesh are facing myriad difficulties that should be eradicated.

One of the main factors for the labor unrest in the garment's industry of Bangladesh is long working hour. An example is as follows:

Mrs. Razia Sultana is an Assistant Sewing Operator. She used to work in a factory where the rules and regulations were not implemented appropriately. She works from 8 A.M. to 10 P.M. continuously with just an hour's break apart from an hour of lunch break, she only gets some weekend when it is an off peak season or if by chance there is no work remaining. Even when she works such long hours into the night, she is continuously cheated on her overtime payments.

Besides this, the authority shows the negligence towards women workers during their pregnancy period. An example is as follows:

Mrs. Ruma Akter, also an Assistant Sewing Operator, says that there is a provision for maternity leave in the law. Yet, if found someone pregnant, the factory authorities would tactfully find out faults in the work done by that female worker or find something wrong with her character in order to fire her from the job. Then the female workers, in order to save face from such allegations, would be forced to leave their jobs. If anyone protests against such injustice, that person is fired from his/her job too.

Workers' clash with the management occurs for arrear salary and bonuses especially during the Eid festivals. An example is as follows:

Mrs. Rikta is a Button Machine Assistant. She has been working for three months in a factory. But she didn't get any salary for those months. After one month of joining, an operator said that here old beggars don't get fed, yet new beggars await food. This factory had so many troubles that she came to know later.

The results indicate the lack of congenial working environment in the garment's industries of Bangladesh. An example is as follows: 
Mrs. Bilkis Akter, an experienced Knitting and Linking Machine Operator, is facing an abusive working environment in her factory. Workers are often verbally abused. In fact, if a worker arrives one minute late to work, he/she is deprived of attendance bonus. Sometimes they don't get two or three month's unpaid salaries. She says that the owners of garment's factories should not treat the workers with negligence.

The results also point out that workers don't receive any residential or transportation facilities. An example is as follows:

Mrs. Sultana Akter has been working as a Buttonhole Machine Assistant in a garment's factory for three years. She lives in a remote place because of low paid rented house. It usually takes two and half hours to come in her factory. But the authority doesn't provide any residential or transportation facilities towards the workers that, in turn, cause the late arrival in the factory. She also opinions that the workers are not paid any medical allowance for their illness.

The result also indicates that the workers of garment's industry in Bangladesh are often deprived of reasonable salary. An example is as follows:

Mr. Shahin Rastogir, a General Color Tuning Machine Operator, is working in a factory. He started working in 2015 in this factory. He states that the workers spend 5 to 8 hours of overtime daily (often 7 days a week) throughout their employment to meet their bare needs of food and shelter; despite their salary is far too low in the perspective of Dhaka, Bangladesh. The management frequently uses bad language towards workers if the workers request to raise their salaries.

Meanwhile the results also show that the workers of the garment's industry in Bangladesh are not normally provided with life insurance. An example is as follows:

Mr. Bidhan Sarker is a Weaving, Knitting and Linking Machine Operator. He works throughout the week for long hours. Sometimes he gives an extra effort to fulfill the orders of foreign buyers. At that time, he has to work 14 to 16 hours per day. But if the foreign buyers cancel order for any defect, then the authority doesn't provide any overtime to him. These types of high working pressures show a possible health risk and urge a mandatory life insurance. But the workers are not provided with any life insurance by the authority for the safety of his/her family.

In addition, the results state that the workers are often experienced with sudden layoff from job. An example is as follows: 
Mrs. Rokeya Begum, an Assistant Sewing Operator, says that the General Manager of her factory is very rude to the workers. She opinions that the sudden layoff occurs due to several reasons e.g. reduction in Return on Investment, lower performance of the workers due to long-term illness, maternity period of the women workers etc. Even If a woman worker lost her job due to the negligence of a supervisor, the blame would be given to the worker.

The results also reveal that sexual harassment especially towards the women workers is a common incidence in the garment's industry of Bangladesh. An example is as follows:

Mrs. Rahima is a Line Iron Man. She states that the workers have to do irregular duties and would have to do full time night duty as overtime. The female workers would have to face sexual harassment from the male staff. They could not say anything in protest because of the fear of losing their jobs and embarrassment.

Finally the study also discloses that the political instability may also create labor unrest in the garment's industry of Bangladesh. An example is as follows:

Mr. Joynal, a Chief Quality Controller, states that the labor unrest also takes place at a time when the main opposition party is also leading a movement for political reforms in the country. The countrywide deadlock disrupted normal life, affecting communications, economic and other activities. He suggests that the political stability is a prerequisite for rapid growth in garment's industry of Bangladesh.

\section{Analysis of the stories}

The findings of the story illustrate different causes that create labor unrest in the garment's industry of Bangladesh. The collected stories have been analyzed below with its respective impacts on labor attitudes:

\begin{tabular}{|c|c|c|}
\hline $\begin{array}{l}\text { No. of } \\
\text { Stories }\end{array}$ & Causes of Labor Unrest & Consequences of Labor Unrest \\
\hline Story-1 & Long working hour & $\begin{array}{c}\text { Lack of job satisfaction } \\
\text { Creation of mental and physical illness } \\
\text { Lack of time to look after family }\end{array}$ \\
\hline Story-2 & $\begin{array}{c}\text { Negligence towards women } \\
\text { workers during pregnancy period }\end{array}$ & Afraid of losing job \\
\hline Story-3 & $\begin{array}{c}\text { Arrear salary and deprivation of } \\
\text { bonuses }\end{array}$ & $\begin{array}{l}\text { Lack of job satisfaction } \\
\text { Lack of work motivation }\end{array}$ \\
\hline Story-4 & $\begin{array}{c}\text { Lack of congenial working } \\
\text { environment }\end{array}$ & $\begin{array}{l}\text { Probable health risk } \\
\text { Job switching }\end{array}$ \\
\hline Story-5 & $\begin{array}{l}\text { Deprivation of residential or } \\
\text { transportation facilities }\end{array}$ & $\begin{array}{c}\text { Difficulty in maintaining the working } \\
\text { schedule }\end{array}$ \\
\hline Story-6 & Deprivation of reasonable salary & Lack of job satisfaction \\
\hline
\end{tabular}




\begin{tabular}{|c|c|c|}
\hline & & Job switching \\
\hline Story-7 & Devoid of life insurance & Raising the future uncertainty \\
\hline Story- 8 & Sudden layoff from job & Augmentation of job insecurity \\
\hline Story-9 & $\begin{array}{l}\text { Sexual harassment especially } \\
\text { towards the women workers }\end{array}$ & Demotivation towards the job \\
\hline Story-10 & Political instability & $\begin{array}{l}\text { Disruption of normal life } \\
\text { Losing of foreign buyers } \\
\text { Hindering economic growth }\end{array}$ \\
\hline
\end{tabular}

Table-3: Snapshot of the stories regarding causes and consequences of labor unrest in Garment's industry of Bangladesh

Among the stated 10 stories, we find several causes behind labor unrest e.g. long working hour, negligence towards women workers during pregnancy period, arrear salary and deprivation of bonuses, lack of congenial working environment, deprivation of residential or transportation facilities, deprivation of reasonable salary, devoid of life insurance, sudden layoff from job, sexual harassment especially towards the women workers and political instability. In this case, thousands of workers came out on the street to form crowds and then went into rampage for long time. These causes beget myriad adverse impacts on labor attitudes. Such as, the workers are not satisfied with their current job. That's why; the job switching is enhancing in high percentage. As a result, both the owners and the workers of the garment's industry are encountering immense complications.

\section{Recommendations}

At the end of the study, we highly appreciate and recommend the owners and managers of garments industry to take new initiatives for resolving the problem of labor unrest in Bangladesh. The recommendations are discussed in the following paragraphs.

The crucial reason of workers clash is coined from postponement of salary and bonuses. Some garments owners are reluctant to pay monthly salary as well as festival bonuses. salary should be given the top most priority to evade unrest in the RMG factories. Some RMG owners make irrational delay to pay the overtime bill to the workers. The government needs to take the strong policy to resolve the issue such as penalizing the owners who do not pay or making delay. The managers of garments industry should maintain a hygienic working atmosphere. The owner should provide healthy and safe environment as per labor law. There are rights for labors but not enough implementation. It must be monitored if the rights are properly implemented or not. And there should be a rating policy based on this and some other factors too.

Factory owners and garments workers are two most vital players in RMG industry. They are complementary to each other. Good relationship 
between them is indispensable for the lift of the industry. But there is a communication gap between them. Factory owners should listen to demands of workers .To avert further unrest, it is crucial to shrinkage the gap between the owners and workers of garments factories.

There are many intelligence agencies, they should also intervene to avert these kinds of conflicts, and both public and private should work together to develop themselves and bring a positive work atmosphere. Finally for a booming industry like RMG, maintaining law and order situation in the industrial area is very important. To be successful, overall the existing Human Resource Development status activities need to be improved.

\section{Implications, limitations, future research and conclusion Implications for research and practice}

This research paper contributes to the literature on the state of garments industry by exploring the actual causes and consequences of labor unrest in this sector. Garments industries are playing a vitally important role for the economic development of Bangladesh. This industry has a paramount importance in the economy of Bangladesh. In this regard, researchers have a special research interest towards the various aspects of garments industries. We do believe that this research advances the study of labor unrest in garments industry that, in turn, will keep a significant contribution towards theoretical basis for further studies on labor unrest existed in the other developing and developed countries.

This study also contributes to take some new initiatives for the development of RMG industry in Bangladesh. Here the details of causes and consequences of labor unrest are discussed along with the details theoretical information that can lead to get some further development strategies to reduce the industrial dispute. The owners and managers of garments industry can get a good idea about the beneath roots of workers clash from this study. These causes and consequences can lead the managers to take further steps to eradicate the problem of workers dispute.

From the practical point of view, the overall findings of the study may help the managers of garments industry to know the details about the causes and consequences of labor unrest that, in turn, can lead to generate some new steps to solve the problem of labor unrest. The findings of the study suggest that investigating the incidents of labor unrest and following up the recommendations is an important attempt to solve the problem.

This study also helps to identify some limitations regarding the garments industry of Bangladesh. So we do believe that this research will help the garment owner to be careful about these troubles existing in the RMG industry. 


\section{Limitations and future research}

Limitations of the study provide avenues for future research opportunities. This study has been conducted to represent the conflict scenarios in the garments industries in Bangladesh. Unrest and conflict in this industry is very common phenomenon. A major limitation of this study is the small sample size. A further research will be conducted on a large scale to analyze and find out the solution regarding labor unrest in Bangladesh. The reason of isolating the study to a single country and a specific industry facilitates the data collection. Future studies can be expanded to other labor centric business industries (e.g. construction, leather, agriculture etc.) in Bangladesh or other countries, allowing the generalization of the results. This study can provide a theoretical basis for further studies on labor unrest existed in the other developing and developed countries.

\section{Conclusion}

This study has given an account of and the reason for the causes of labor unrest in the RMG industry of Bangladesh. The objective of this study is to find out the causes and consequences of labor unrest. The responses of the respondents reveal that long working hour, low wage, irregularities in payment, negligence towards women workers during pregnancy period, lack of congenial working environment, deprivation of residential or transportation facilities, devoid of life insurance, sudden layoff from job, sexual harassment especially towards the women workers and political instability are the major causes of labor unrest that are identified from this study. These factors are responsible for the labor unrest in ready-made garment industry of Bangladesh. The causes are to be diagnosed through investigation. Findings of the study suggest that exploring the incidents of labor unrest is needed to solve the problem. Finally, it can be concluded that if all the key player including the workers association, the owners/managers, and the Government associated to this industry considered the factors identified through this study in making their policy, the situation might be changed and improved.

\section{References:}

1. Abdullah, A. (2005). Productivity Development is a Very Crucial Way Out to Face the Post Multi Fiber Agreement Challenges for Bangladesh. Journal of Business Administratio, 31(3), 107-129.

2. Abrar, A. (2007). Labor unrest in Clothing Industry: Reasons and Solutions. Bangladesh Textile Today, First Ever Complete Web Solution for the Textile and Apparel Industry. 
3. Absar \& Syeda, S. (2001). Problem surrounding wages: The Readymade Garment sector in Bangladesh. Labor and Management Development Journal, 2(7).

4. Absar, S. (2001). Problems Surrounding Wages: Readymade Garments Sector in Bangladesh. Labour and Management in Development, 2 (7), 2-17.

5. Ahmed, S., Raihan, M., \& Islam, N. (2013). Labor Unrest in the Ready-Made Garment Industry of Bangladesh. International Journal of Business and Management, 8(15), 68-80. http://dx.doi.org/10.5539/ijbm.v8n15p68

6. Bangladesh, R. (2017). Labor Unrest at Ashulia | RMG Bangladesh. Rmgbd.net. Retrieved 27 November 2017, from http://rmgbd.net/labour-unrest-at-ashulia/

7. Clark, C. \& Kanter, S. (2010). Violence in the Readymade Garments (RMG) Industry in Bangladesh. Center for International and Comparative Studies, 3 (1), 6-12.

8. Hasan, K., Islam, A., \& Arifuzzaman, M. (2015). A Study on the Major Causes of Labour Unrest and Its Effect on the RMG Sector of Bangladesh. International Journal of Scientific \& Engineering Research, 6(11), 199-212.

9. Hossain, H., Jahan, R., \& Sobhan, S. (1990). No Better Option? Industrial Women Workers in Bangladesh. University Press Limited.

10. Islam, M. \& Ahmed, S. (2010). Contemplating Sustainable Solutions to Garments Sector Unrest. The Daily Star, 10 July.

11. Islam, M. (1984). Notes on the Growth of Bangladesh Garments Industry. The Journal of Management Business and Economics, 10(4), 536-550.

12. Islam, M., \& Zahid, D. (2012). Socioeconomic Deprivation and Garment Worker Movement in Bangladesh: A Sociological Analysis. American Journal of Sociological Research, 2(4), 82-89.

13. Jamaly, R. \& Wickramanayake (1996). Women Workers in the Garment Industry in Dhaka, Bangladesh. Development in Practice, 6(2), 150-160.

14. Kamal, M., Billah, M., \& Hossain, S. (2012). Labor Unrest and Bangladesh Labor Act 2006: A Study on Ready Made Garment Factories in Gazipur. Journal of Business and Technology (Dhaka), 5(2), 1-18. http://dx.doi.org/10.3329/jbt.v5i2.9932

15. Mohammad, S. \& Sonia, A. (2010). Contemplating Sustainable Solutions to Garments Sector Unrest. The Daily Star.

16. Paul-Majumder, P. (1998). Health Status of the Garment Workers in Bangladesh: Findings from a Survey of Employers and Employees. 
Bangladesh Institute of Development Studies, Dhaka, 24 (1), 204225.

17. Paul-Majumder, P. (2007). Bangladeshe Poshak Shilpa Khetre SamaAdhikarer Abastha Ebong Sramik Ashantosher Sharup. Bangladesh Unnayan Shamiksha, 24(33), 1413.

18. Rahman, M., Bhattacharya, D., \& Moazzem, K. (2008). Bangladesh Apparel Sector in Post MFA Era: A Study on the Ongoing Restructuring Process. Centre for Policy Dialogue in association with IFC and SEDF, Dhaka.

19. Refayet, U. (2012). Causes of RMG Unrest. The Daily Star, 6(8).

20. Safi, M. (2016). Bangladesh garment factories sack hundreds after pay protests. The Guardian. Retrieved 27 November 2017, from https://www.theguardian.com/world/2016/dec/27/bangladeshgarment-factories-sack-hundreds-after-pay-protests

21. Sarker, M. (1997). Status of the Workers in the Garment Industries of Bangladesh. A Study on Socio-economic Perspective. Journal of Business Studies, 18(1), 153-168.

22. Siddiqi, H. (2005). The Ready Made Garment Industry of Bangladesh. The University Press Limited.

23. The Daily Star. (2012, May). Instigations, Rumors Led To Most Incidents.

24. Uddin, M. \& Jahed, M. (2007). Garments Industry: A Prime Mover of the Social Economic Development of Bangladesh. The Cost and Management, 35(1), 59-70.

25. Uddin, M. \& Jahed, M. (2007). Garments Industry: A Prime Mover of the Social Economic Development of Bangladesh. The Cost and Management, 35(1), 59-70. 